This is an electronic reprint of the original article. This reprint may differ from the original in pagination and typographic detail.

Author(s): Scharnweber, Kristin; Syväranta, Jari; Hilt, Sabine; Brauns, Mario; Vanni, Michael J.; Brothers, Soren; Köhler, Jan; Knezevic-Jaric, J.; Mehner, Thomas

Title: $\quad$ Whole-lake experiments reveal the fate of terrestrial particulate organic carbon in benthic food webs of shallow lakes

Year: $\quad 2014$

Version:

Please cite the original version:

Scharnweber, K., Syväranta, J., Hilt, S., Brauns, M., Vanni, M. J., Brothers, S., Köhler, J., Knezevic-Jaric, J., \& Mehner, T. (2014). Whole-lake experiments reveal the fate of terrestrial particulate organic carbon in benthic food webs of shallow lakes. Ecology, 95(6), 1496-1505. https://doi.org/10.1890/13-0390.1

All material supplied via JYX is protected by copyright and other intellectual property rights, and duplication or sale of all or part of any of the repository collections is not permitted, except that material may be duplicated by you for your research use or educational purposes in electronic or print form. You must obtain permission for any other use. Electronic or print copies may not be offered, whether for sale or otherwise to anyone who is not an authorised user. 


\title{
Whole-lake experiments reveal the fate of terrestrial particulate organic carbon in benthic food webs of shallow lakes
}

\author{
K. Scharnweber, ${ }^{1,2,3}$ J. Syväranta, ${ }^{1,4}$ S. Hilt, ${ }^{1}$ M. Brauns, ${ }^{1,5}$ M. J. Vanni, ${ }^{1,6}$ S. Brothers, ${ }^{1,7}$ J. Köhler, ${ }^{1}$ \\ J. KNEŽEVIĆ-JARIĆ, ${ }^{1,8}$ AND T. MEHNER ${ }^{1}$ \\ ${ }^{1}$ Leibniz-Institute of Freshwater Biology and Inland Fisheries, Müggelseedamm 310, 12587 Berlin, Germany \\ ${ }^{2}$ Freie Universität Berlin, Königin-Luise-Straße 1-3, 14195 Berlin, Germany
}

\begin{abstract}
Lake ecosystems are strongly linked to their terrestrial surroundings by material and energy fluxes across ecosystem boundaries. However, the contribution of terrestrial particulate organic carbon (tPOC) from annual leaf fall to lake food webs has not yet been adequately traced and quantified. In this study, we conducted whole-lake experiments to trace artificially added tPOC through the food webs of two shallow lakes of similar eutrophic status, but featuring alternative stable regimes (macrophyte rich vs. phytoplankton dominated). Lakes were divided with a curtain, and maize (Zea mays) leaves were added, as an isotopically distinct tPOC source, into one half of each lake. To estimate the balance between autochthonous carbon fixation and allochthonous carbon input, primary production and tPOC and tDOC (terrestrial dissolved organic carbon) influx were calculated for the treatment sides. We measured the stable isotope ratios of carbon $\left(\delta^{13} \mathrm{C}\right)$ of about 800 samples from all trophic consumer levels and compared them between lake sides, lakes, and three seasons. Leaf litter bag experiments showed that added maize leaves were processed at rates similar to those observed for leaves from shoreline plants, supporting the suitability of maize leaves as a tracer. The lake-wide carbon influx estimates confirmed that autochthonous carbon fixation by primary production was the dominant carbon source for consumers in the lakes. Nevertheless, carbon isotope values of benthic macroinvertebrates were significantly higher with maize additions compared to the reference side of each lake. Carbon isotope values of omnivorous and piscivorous fish were significantly affected by maize additions only in the macrophytedominated lake and $\delta^{13} \mathrm{C}$ of zooplankton and planktivorous fish remained unaffected in both lakes. In summary, our results experimentally demonstrate that $\mathrm{PPOC}$ in form of autumnal litterfall is rapidly processed during the subsequent months in the food web of shallow lakes and is channeled to secondary and tertiary consumers predominantly via the benthic pathways. A more intense processing of tPOC seems to be connected to a higher structural complexity in littoral zones, and hence may differ between shallow lakes of alternative stable states.
\end{abstract}

Key words: allochthony; omnivorous fish; shallow lakes; stable isotope analysis; terrestrial carbon; whole-lake experiment.

Manuscript received 28 February 2013; revised 1 July 2013; second revision 5 December 2013; accepted 10 December 2013. Corresponding Editor: P. R. Leavitt.

${ }^{3}$ E-mail: scharnweber@igb-berlin.de

${ }^{4}$ Present address: Department of Biological and Environmental Sciences, PL 35, 40014 University of Jyväskylä, Finland.

${ }^{5}$ Present address: Helmholtz Centre for Environmental Research GmbH -UFZ, Brückstrasse 3a, 39114 Magdeburg, Germany.

${ }^{6}$ Present address: Department of Biology, Miami University, Oxford, Ohio 45056 USA.

${ }^{7}$ Present address: School of Environmental Sciences, University of Guelph, Bovey Building, Gordon Street, Guelph N1G 2W1 Canada.

${ }^{8}$ Present address: Institute for Multidisciplinary Research, University of Belgrade, Kneza Viseslava 1, 11000 Belgrade, Serbia.

\section{INTRODUCTION}

Lakes have historically been considered ideal model ecosystems due to their well-defined boundaries with the surrounding terrestrial environment. However, recent evidence suggests a tight coupling with terrestrial ecosystems via reciprocal fluxes of energy and nutrients that can strongly subsidize the food webs of recipient habitats (Jones 1992, Cole et al. 2006, Jansson et al. 2007). For many small lakes, terrestrial subsidies may substantially complement autochthonous (internally produced) production (Schindler and Scheuerell 2002, Babler et al. 2011).

Within the context of global carbon cycling, the role and fate of organic carbon (OC) may be of particular interest because lakes are hotspots for carbon cycling (Tranvik et al. 2009). Organic carbon from adjacent landscapes can enter aquatic food webs in different forms (Cole et al. 2006), for example, as terrestrial 
animals that fall into water (e.g., insects) and become prey of aquatic consumers (Mehner et al. 2005). Further, the contribution of dissolved OC (DOC) to lake food webs is significant and relatively well studied (Karlsson et al. 2003, Kritzberg et al. 2004). The third OC form, terrestrial particulate organic carbon (tPOC), enters lakes primarily at the land-water interface, i.e., the littoral zone (Wetzel 1992), where it is processed by microbial communities, zooplankton, or macroinvertebrates (Jones et al. 1999, Karlsson et al. 2003, Pace et al. 2007). By consuming zooplankton and benthic macroinvertebrates, higher trophic levels (fish, predatory macroinvertebrates) may also derive a significant contribution of tPOC (Solomon et al. 2008, Weidel et al. 2008).

This conceptual view of the fate of tPOC in lake ecosystems has been tested previously by using $\mathrm{NaH}^{13-}$ $\mathrm{CO}_{3}$ as a tracer to elevate the $\delta^{13} \mathrm{C}$ of dissolved inorganic carbon used by photosynthetic organisms and enhance the separation between autochthonous and allochthonous OC (Carpenter et al. 2005, Cole et al. 2006, Weidel et al. 2008). This indirect approach bears some uncertainty because the contribution from old, unlabeled detritus cannot be split into autochthonous and terrestrial origin (Solomon et al. 2008, Weidel et al. 2008) and because the addition of $\mathrm{NaH}^{13} \mathrm{CO}_{3}$ may not label metalimnetic phytoplankton (Francis et al. 2011). A recent study included stable isotope ratios of hydrogen to overcome this problem and confirmed high allochthony of macroinvertebrates and intermediate levels of allochthony of fish (Solomon et al. 2011). To our knowledge, only one study has experimentally and directly traced the fate of tPOC in lentic systems. Bartels et al. (2012) added tPOC as fine particles (cornstarch) to the sediment surface of lake enclosures without fish and found that $\delta^{13} \mathrm{C}$ values shifted in macroinvertebrates and zooplankton. However, the application of fine particulate cornstarch does not truly mimic the naturally dominant tPOC input by litterfall and prevents the potential utilization of tPOC by macroinvertebrate shredder species, which are a numerically important compartment of lake food webs (Heino 2008). Hence, we lack a thorough understanding of the importance of seasonally pulsed tPOC inputs to benthic and pelagic food webs in lakes relative to autochthonous carbon fixation.

We conducted whole-lake experiments to follow the fate of artificially added tPOC in the food webs of two shallow lakes. Globally, shallow lakes are the most common lake type (Downing et al. 2006) and commonly exhibit two alternative stable regimes: a clear-water regime typified by submerged macrophytes or a turbid regime typified by a high phytoplankton biomass (Scheffer et al. 1993). The physical structures of submerged macrophytes provide spatial and trophic niches for macroinvertebrates (Gresens 1995). Vegetated zones thus typically support a greater abundance, biomass, and diversity of macroinvertebrates compared to open waters (Pardue and Webb 1985, Beckett et al. 1992, Hargeby et al. 2007), and omnivorous fish may feed to a higher degree on benthic macroinvertebrates if abundance of benthic prey is high relative to pelagic prey (Okun et al. 2005). It can thus reasonably be assumed that macroinvertebrate processing of leaf tPOC contributes to food webs differently in lakes of alternative stable regimes.

To cover the potential range of responses, we incorporated one lake of each alternative regime into our experimental design. Both lakes were divided, and maize leaves (Zea mays (L.)), with their distinctly elevated $\delta^{13} \mathrm{C}$ values, were added to one side of each lake in autumn. Simultaneously, the lakes received natural tPOC loads from the surrounding landscape. Our experiment therefore mirrored both the type of tPOC that naturally enters the lakes, as well as the spatial and temporal distribution of the natural entry into the littoral zone. We hypothesized that the use of added tPOC could be traced up to higher trophic levels of food webs in both lakes, as indicated by increased stable carbon isotope values of benthic and pelagic consumers of lake sides with maize additions compared to those in the untreated reference sides. We further calculated the influx of organic carbon and primary production in the treatment sides of both lakes to assess whether the artificial tPOC input was within the range of the ambient tPOC inputs and to compare this flux to autochthonous carbon fixation. Finally, we expected a difference in the intensity of the response between the lakes, specifically a stronger effect of maize additions in the lake that had a greater area covered with macrophytes, because the denser colonization by macroinvertebrates may support the processing of tPOC.

\section{Material And Methods \\ Study sites and experimental design}

Our experiment was conducted in two eutrophic, shallow lakes located in northeastern Germany (Table 1). Kleiner Gollinsee (hereafter referred to as Gollinsee) is turbid and dominated by phytoplankton, whereas Schulzensee has higher water clarity and approximately $22 \%$ of the lake area is colonized by submerged macrophytes (Ceratophyllum submersum L.). Both lakes are surrounded by alder trees (Alnus glutinosa (L.) Gaert.) and reed stands (Phragmites australis (Cav.) Trin. Ex Steud.). Floating-leaved macrophytes (Nymphaea alba L. and $N$. lutea (L.)) grow in both lakes and cover $3 \%$ of the total lake area in Gollinsee and $12 \%$ in Schulzensee. The lakes were both classified as eutrophic due to comparable elevated ambient nutrient concentrations (Table 1).

In October 2010, we used plastic curtains to divide both lakes, thereby producing two similar halves within each lake, based on the hydrology and morphology of the lakes (Table 1). The curtains were sealed in the sediment and isolated the water volume of each half. At the beginning of the experiment (November 2010), we 
TABLE 1. Characteristics of the studied lakes.

\begin{tabular}{ccccccccc}
\hline \hline Lake & \multicolumn{1}{c}{$\begin{array}{c}\text { Stable } \\
\text { regime }\end{array}$} & $\begin{array}{c}\text { Area } \\
\left(\mathrm{m}^{2}\right)\end{array}$ & $\begin{array}{c}\text { Mean } \\
\text { depth }(\mathrm{m})\end{array}$ & $\begin{array}{c}\text { Volume of } \\
\text { treatment } \\
\text { side }\left(\mathrm{m}^{3}\right)\end{array}$ & $\begin{array}{c}\text { Volume of } \\
\text { reference } \\
\text { side }\left(\mathrm{m}^{3}\right)\end{array}$ & $\begin{array}{c}\text { Secchi } \\
\text { depth }(\mathrm{m})\end{array}$ & $\begin{array}{c}\text { TP } \\
(\mu \mathrm{g} / \mathrm{L})\end{array}$ & $\begin{array}{c}\text { Annual C load } \\
\text { by alder leaves } \\
\left.\left(\mathrm{g} \cdot \mathrm{C} \cdot \mathrm{m}^{-2} \cdot \mathrm{yr}\right)^{-1}\right)\end{array}$ \\
\hline Gollinsee & $\begin{array}{c}\text { turbid, phytoplankton } \\
\text { dominated } \\
\text { Schulzensee }\end{array}$ & 33202 & 1.7 & 23290 & 33843 & $1.1 \pm 0.3$ & $38.6 \pm 8.1$ & 7.2 \\
& $\begin{array}{c}\text { clear, macrophyte } \\
\text { dominated }\end{array}$ & 39132 & 2.3 & 41777 & 47793 & $1.7 \pm 0.1$ & $34.1 \pm 6.4$ & 6.4 \\
\hline
\end{tabular}

Notes: For transparency measured as Secchi depth and total phosphorus (TP), monthly mean values $( \pm \mathrm{SD})$ of reference and treatment sides ( $N=12$ months) for the year 2011 are shown. For TP, water samples were taken in the pelagic and littoral zones.

added roughly $2 \mathrm{Mg}$ of coarsely shredded fresh maize leaves and stems (without cobs) into one half of Gollinsee $\left(25 \mathrm{~g} \mathrm{C} \cdot \mathrm{m}^{-2} \cdot \mathrm{yr}^{-1}, \mathrm{C}\right.$ content measured by a Vario EL CHNOS Element Analyzer [elementar Analysensysteme $\mathrm{GmbH}$, Hanau, Germany]) and $3 \mathrm{Mg}$ to one half of Schulzensee $\left(28 \mathrm{~g} \mathrm{C} \cdot \mathrm{m}^{-2} \cdot \mathrm{yr}^{-1}\right.$; subsequently referred to as treatment sides as compared to nontreated reference sides). We assumed maize leaves to be a food source of equal quality to common tree leaves of the temperate zone with a $\mathrm{C}: \mathrm{N}$ ratio of $41.1 \pm 0.9$ (mean \pm $\mathrm{SD}$ ), which is similar to European beech (Fagus sylvatica L.), European hornbeam (Carpinus betulus L.), and Norway maple (Acer platanoides L.; Jacob et al. 2010). The quantity of maize carbon added (per unit area) was approximately four times higher than the estimated lake-specific areal input of terrestrial carbon by alder leaves, which occurred at the same time as the addition of maize leaves (Table 1). Maize is a $\mathrm{C}_{4}$ plant, which is naturally enriched in $\delta^{13} \mathrm{C}$ (mean $\delta^{13} \mathrm{C},-13.5 \%$ \% $1.8 \%$ 。 [mean $\pm \mathrm{SD}$ ], compared to $-28.4 \%$ $\pm 0.7 \%$ of alder leaves [Smith and Epstein 1971]). This difference enables the tracing of added $\mathrm{POC}$ if it is incorporated into the food web (Bartels et al. 2012), which is useful because the $\delta^{13} \mathrm{C}$ ranges of autochthonous resources and terrestrial $\mathrm{C}_{3}$ plants often overlap (Meyers and LallierVerges 1999).

For the treatment sides of both lakes, we calculated the autochthonous organic carbon production of macrophytes, periphyton, and phytoplankton. Furthermore, we calculated the input by tDOC (terrestrial dissolved organic carbon; see Brothers et al. 2013a,b) and the tPOC influx from alder and maize (see Appendix A for details of methods) to document that the pulsed POC input from maize was relatively minor in comparison with the autochthonous carbon fixation in the lakes.

\section{Maize leaf degradation}

To assess whether maize leaves are processed at a rate comparable to that of natural tPOC sources such as alder and reed leaves, we conducted a litter bag experiment with maize leaves and compared the rates obtained in the lakes with degradation rates of other leaves from the literature. A total of 36 litter bags (nine per site and lake), each containing $10 \mathrm{~g}$ of dried maize leaves, were placed in the littoral zone of the studied lakes immediately after the addition of the maize leaves in November 2010. Bags featured a 1-cm mesh size to allow macroinvertebrates access. Sampling was conducted in March, June, and August 2011, with three replicates being retrieved at each time of sampling for the assessment of litter dry mass (drying at $60^{\circ} \mathrm{C}$ until mass constancy).

\section{Sampling procedure and stable isotope analysis}

In 2011, we sampled all consumers (zooplankton, macroinvertebrates, and fish) for stable isotope analysis from treatment and reference sides in both lakes in spring (April), summer (June), and autumn (September). Zooplankton was sampled by hauling nets (mesh sizes, $55 \mu \mathrm{m}$ and $100 \mu \mathrm{m}$ ) through the whole water column. Zooplankton biomass consisted mainly of cyclopoid copepods (Ehrlich 2012, but see Appendix B for a species list). Samples were transferred to nonchlorinated tap water and stored in a refrigerator overnight to allow zooplankton individuals to void their guts. The next day, samples were filtered on $100-\mu \mathrm{m}$ filters. Macroinvertebrates were collected with a kick net (mesh size, 500 $\mu \mathrm{m})$ from several eulittoral and sublittoral locations, whereas no macroinvertebrates were found in the deeper benthic zone devoid of macrophytes. Macroinvertebrates were sorted into major taxonomic groups (see Appendix B for a species list) and held in nonchlorinated tap water overnight to allow emptying of their guts. Additional macroinvertebrate samples (21\% of total sample number) were taken from leaf litter bags. There was no difference in carbon isotope values between randomly collected individuals of Chironomidae, Trichoptera, and Ephemeroptera larvae from the treatment side and individuals from leaf litter bags $(t \leq 1.175, P \geq$ 0.252 ), but values differed for Isopoda (Gollinsee, $t_{13}=$ $-3.218, P=0.007$; Schulzensee, $t_{26}=-4.841, P<0.001$ ). Therefore, we pooled the samples from different origins within benthic groups for subsequent analyses, but repeated the statistical tests (see Results) for Isopoda by excluding all individuals from the litter bags.

Fish were sampled by Nordic multi-mesh gill nets (Lundgrens Fiskredskapsfabrik AB, Stockholm, Sweden) and electrofishing. Fish species included sunbleak (Leucaspius delineatus, Heckel), roach (Rutilus rutilus L.), rudd (Scardinius erythrophthalmus L.), tench (Tinca tinca L.), perch (Perca fluviatilis L.), and pike (Esox 
lucius L.). Fish were measured, weighed, and immediately stored on ice. In the laboratory, a small amount of dorsal muscle tissue was removed and placed on aluminum foil.

All samples for stable isotope analysis were oven dried at $60^{\circ} \mathrm{C}$ for $48 \mathrm{~h}$, ground to a fine powder using a mortar and pestle, and then weighed into tin capsules by using about $0.5 \mathrm{mg}$ dry mass (dm). Elemental and stable isotope analyses of carbon and nitrogen were conducted at the University of Jyväskylä, Finland, using a FlashEA 1112 elemental analyzer (Thermo Electron, Waltham, Massachusetts, USA) coupled to a Thermo Finnigan DELTA Plus Advantage mass spectrometer (Thermo Electron Corporation, Waltham, Massachusetts, USA). Results are expressed in the $\delta$ notation, using ratios of samples and international standards (PeeDee Belemnite for $\delta^{13} \mathrm{C}$, atmospheric $\mathrm{N}$ for $\delta^{15} \mathrm{~N}$ ). Analytical error (mean SD from in-house standard) for each run was always smaller than $0.3 \%$ for $\delta^{13} \mathrm{C}$ and $\delta^{15} \mathrm{~N}$.

\section{Calculations and statistical analysis}

For statistical analyses, we averaged the isotopic values across Ephemeroptera and Trichoptera taxa due to their very similar values. Predatory macroinvertebrates (Odonata, Hirudinea, and Coleoptera) were pooled into one group. We grouped fish species into omnivorous (roach, rudd, tench, and perch smaller than $15 \mathrm{~cm}$ ), planktivorous (sunbleak and omnivorous fish smaller than $5 \mathrm{~cm}$ ), and piscivorous (pike) feeding guilds. Due to a severe natural fish kill over the 20092010 winter season, no large piscivorous perch were caught, and the sample size of pike was low.

Fish $\delta^{15} \mathrm{~N}$ values were log-transformed to obtain normally distributed data. Subsequently, assumptions of normal distribution and homogeneity of variances were met for all analyses. Isotopic data $\left(\delta^{13} \mathrm{C}\right.$ and $\delta^{15} \mathrm{~N}$ ) were analyzed using linear mixed models (RM LMM) with main factors lake, lakeside (maize added or reference), and season (as repeated measure), and all two-way interactions and compound symmetry as covariance type. For zooplankton, only one sample per season was available. For this group, a univariate general linear model (GLM) with lake and lakeside, and their interaction, was calculated. For all significant main effects, estimated marginal means (EMM) were calculated to elucidate the differences between lakes, treatment and reference sides, or seasons. Statistical tests were performed using PASW for Windows v. 17.0 (IBM Corporation, Armonk, New York, USA). For details of all statistical tests, see Appendix C. For the majority of the consumer groups, there was no treatment, lake or seasonal effect on $\delta^{15} \mathrm{~N}$ values (Appendix C), presumably because ambient values were very similar to $\delta^{15} \mathrm{~N}$ of maize. Therefore, we subsequently focus only on the differences in $\delta^{13} \mathrm{C}$ values.

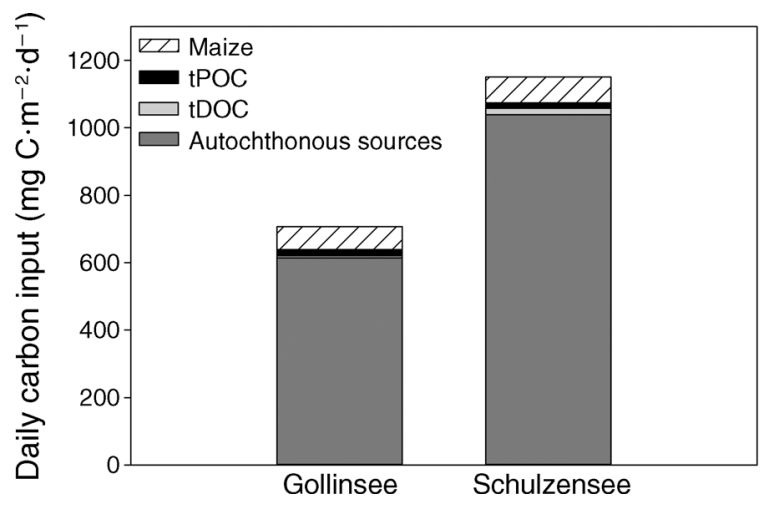

FIG. 1. Daily carbon input of Gollinsee and Schulzensee (treatment sides only). Depicted are values of carbon input as autochthonous sources (from submerged macrophytes [only present in Schulzensee], emergent macrophytes, epiphyton, epipelon, Aphanotece stagnina [a blue-green algae present only in Schulzensee], and phytoplankton), tDOC (terrestrial dissolved organic carbon; via groundwater and precipitation), tPOC (terrestrial particulate organic carbon; from alder leaves in autumn), and experimentally added maize leaves.

\section{RESUlts}

Maize carbon additions were fourfold higher than the tPOC entering the lakes as natural leaf fall from alder trees, but were low (7-10\%) compared to the autochthonous carbon fixation by aquatic primary production (Fig. 1).

Our results of the litter bag experiment show that maize leaves degraded at rates comparable with those for reed (Gessner 2000) and Green Alder (Alnus viridis (Chaix.) D.C; Robinson et al. 1998). After nine months (July 2011), only 20\% (Gollinsee) or 17\% (Schulzensee) of the initial dry mass remained in the litter bags (Fig. 2).

Maize additions significantly elevated $\delta^{13} \mathrm{C}$ values in all benthic consumer groups in both lakes (Fig. 3c, d, e, Table 2) except for predatory macroinvertebrates (Fig. $3 \mathrm{f}$, Table 2), as demonstrated by the linear mixed models. Estimated marginal means (EMM) of $\delta^{13} \mathrm{C}$ were higher in the treatment than in the reference sides for Chironomidae, Ephemeroptera + Trichoptera, and Isopoda. However, there were significant lake $\times$ treatment interactions for all these groups, reflecting that the elevation of carbon values in response to maize addition was stronger in Schulzensee than in Gollinsee (Fig. 3c, d, e).

Elevated $\delta^{13} \mathrm{C}$ values were similarly found for omnivorous and piscivorous fish, primarily in the treatment side of Schulzensee during spring and summer (Fig. 3g, h). However, the significant interaction of treatment and season (Table 2) indicates that the signal in fish completely reversed in autumn relative to the spring and summer data (Fig. 3g, h), causing overall higher EMMs in the reference than in the treatment sides. Similar seasonal effects were found in most benthic consumer groups. EMMs were usually highest 


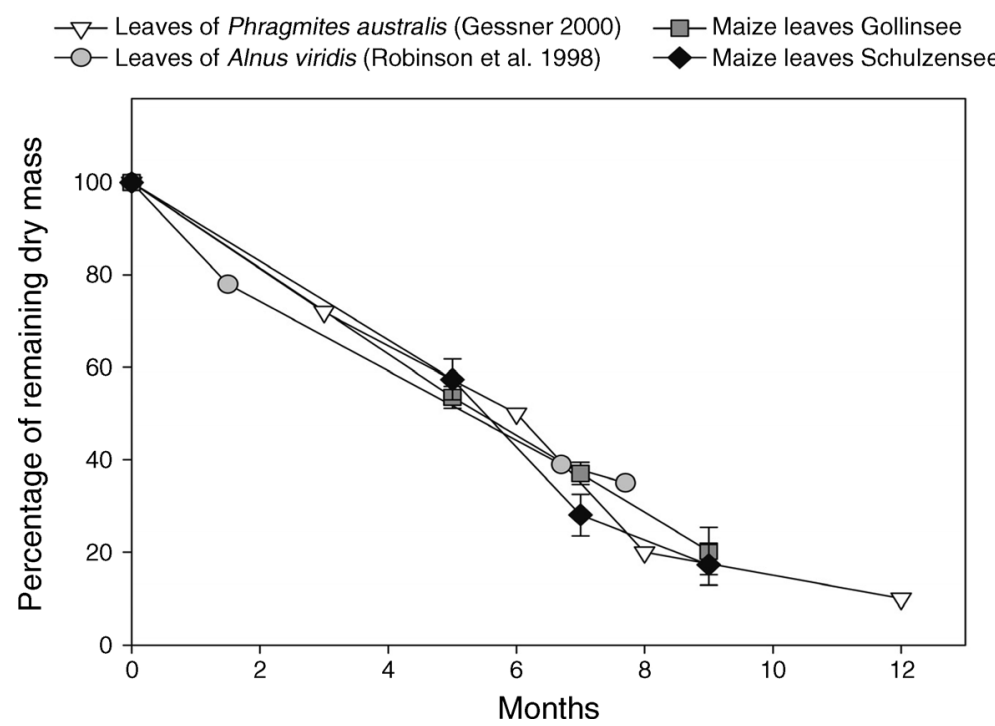

FIG. 2. Breakdown of different leaves as demonstrated by litter bag experiments. Triangles represent results from experiments with leaves of reeds (Phragmites australis (Cav.) Trin. Ex Steud. [Gessner 2000]), circles represent results from green alder (Alnus viridis (Chaix.) D.C) degradation (Robinson et al. 1998), and squares (Gollinsee), as well as diamonds (Schulzensee), represent degradation of maize leaves within our own leaf litter bag experiments, including standard error bars from three replicates each.

in summer, whereas overall low $\delta^{13} \mathrm{C}$ values were found in autumn samples (Fig. 3, Table 2), suggesting that the effects of the maize addition had disappeared by approximately one year after the additions.

There was a significant lake effect (Table 2), with global EMMs of $\delta^{13} \mathrm{C}$ values being higher in turbid Gollinsee than in clear-water Schulzensee in six of eight consumer groups. The higher EMMs in Gollinsee were, however, attributable to a difference in basal carbon isotope values and were not the effect of the maize addition. This was indicated from calculations of the differences in isotope values between treatment and reference sides for macroinvertebrates, omnivorous, and piscivorous fish for spring and summer data (Fig. 4). On average across these groups, maize enhanced the carbon isotope values by $1.73 \%$ in Schulzensee, but only by $0.70 \%$ in Gollinsee. Furthermore, the elevated carbon isotope values of macroinvertebrates were channeled into omnivorous and piscivorous fish only in Schulzensee (Fig. 4), but faded out in Gollinsee by the time energy flow reached the trophic level of omnivorous fishes (no piscivores were caught in the treatment side of this lake until summer). The differently enhanced carbon between the lakes confirmed the significant lake $\times$ treatment interaction found in the statistical analyses (Table 2).

In contrast to the benthic consumers, maize addition did not change $\delta^{13} \mathrm{C}$ values within the pelagic food web (zooplankton and planktivorous fish) in either lake or season (Fig. 3a, b, Table 2).

\section{Discussion}

We demonstrated experimentally that artificially added tPOC could be traced in the food webs of two shallow lakes. In both lakes, several macroinvertebrate taxa had significantly elevated $\delta^{13} \mathrm{C}$ in response to tPOC addition through maize leaves, and in one lake, this signal was also seen in omnivorous and piscivorous fish. This is the first direct experimental evidence that tPOC input to lakes via terrestrial leaves is used by primary consumers and can ultimately be channeled to secondary and tertiary consumers. In contrast, no changes were detected in the pelagic food webs, suggesting that benthic pathways dominate the transformation of tPOC in these lakes. We found a slightly stronger enhancement of $\delta^{13} \mathrm{C}$ in the lake with submerged macrophytes than in the turbid lake, suggesting that the processing and channeling of tPOC in the form of leaves may be facilitated in shallow lakes with structured littoral zones.

To trace the fate of tPOC entering lake food webs in the form of terrestrial leaves, we added the $\mathrm{C}_{4}$ plant maize because of its distinctly elevated $\delta^{13} \mathrm{C}$ relative to the value of phytoplankton, submerged macrophytes, and terrestrial $\mathrm{C}_{3}$ plants. The simultaneous litter bag experiments indicated that maize leaves rapidly degraded at rates similarly reported for Green Alder (Robinson et al. 1998) and reeds (Gessner 2000). These similarities in processing suggest that our addition of maize leaves suitably mimicked the natural input of tPOC by litterfall to lakes. Further support for the suitability of our approach comes from the correspondence between degradation within the litter bags and the temporal persistence of the maize signal in the stable isotope analyses. Differences in $\delta^{13} \mathrm{C}$ values of macroinvertebrates and omnivorous and piscivorous fish between treatments were seasonally distinct and strongest during summer when warm temperatures induced high metabolic requirements and hence the highest feeding rates of 
Reference side $\square$ Treatment side
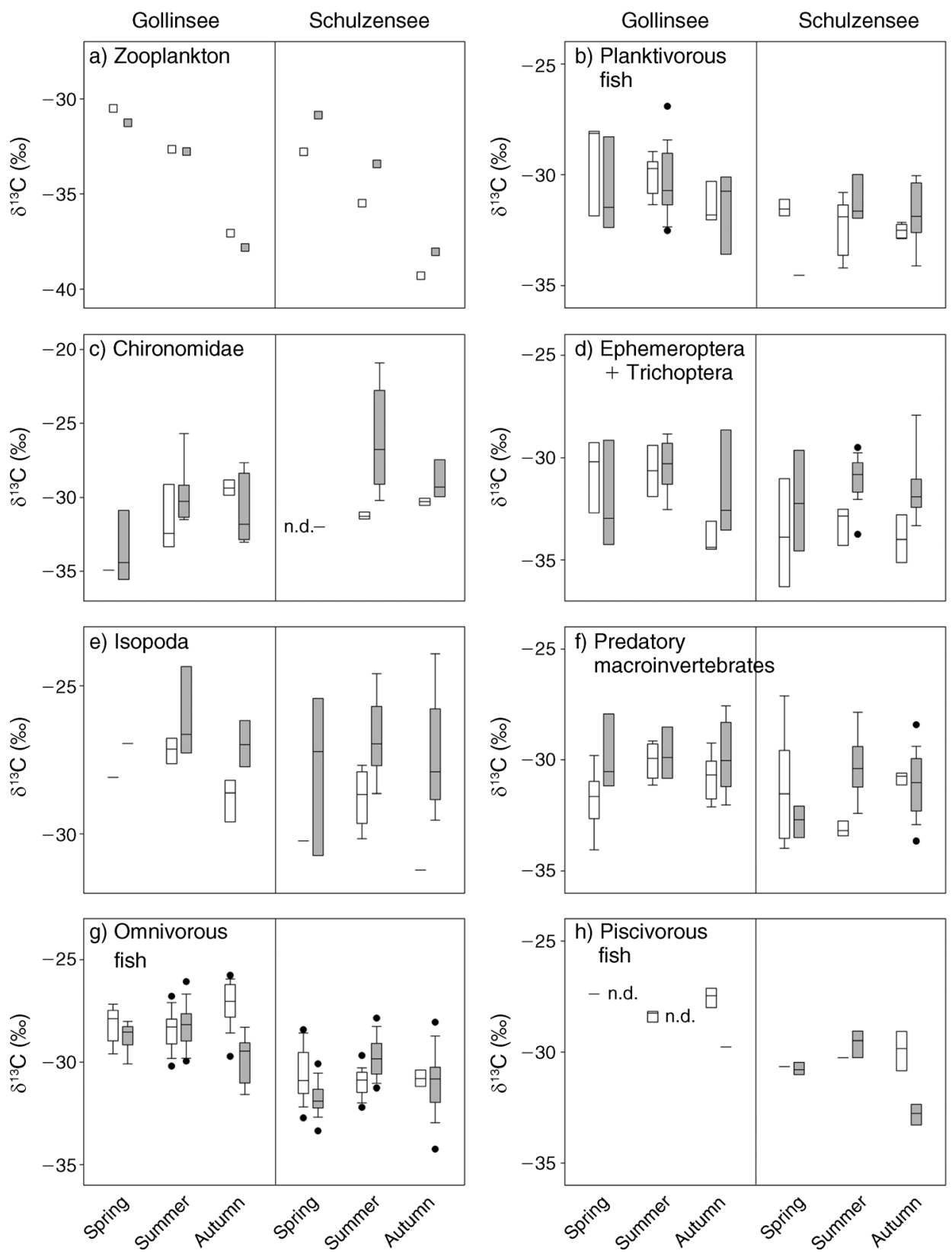

FIG. 3. Boxplots of $\delta^{13} \mathrm{C}$ values of selected taxa, measured from reference (white bars) and treatment (maize addition, gray bars) sides of Gollinsee (turbid and phytoplankton dominated) and Schulzensee (clear and macrophyte dominated) in spring, summer, and autumn 2011. Boxplots with mean values and 25th and 75th percentile are shown, whiskers represent 10th and 90th percentiles, and dots are 5th and 95th percentiles; n.d. represents no data. For three out of 12 occasions, when samples of zooplankton were taken more than once per season, mean values are shown. Note that number of analyzed individuals per box substantially differed (see Table 2).

consumers. Due to isotopic turnover, results from tissue growth, and tissue displacement (Hesslein et al. 1993), these differences in $\delta^{13} \mathrm{C}$ values had disappeared and in part reversed by autumn when the remains of maize leaves in the litter bags were no longer detectable. The lack of maize POC may have forced the consumers to switch to POC from autochthonous sources (e.g., macrophytes, reeds); this dilution of consumer bodies with autochthonous OC could account for the loss of a tPOC signal in autumn. These results confirm the concept that $\mathrm{tPOC}$ input to lakes via litterfall can be considered a seasonally pulsed resource (Nowlin et al. 
TABLE 2. Results of repeated-measure linear mixed models (RM LMM) or univariate general linear models (GLM) with $\delta^{13} \mathrm{C}$ as the dependent variable and treatment, lake, and season and their bivariate interactions as independent variables.

\begin{tabular}{|c|c|c|c|c|c|c|c|c|c|c|c|}
\hline \multirow[b]{3}{*}{ Group } & \multirow[b]{3}{*}{$N$} & \multirow[b]{3}{*}{ Model type } & \multicolumn{9}{|c|}{ Factor } \\
\hline & & & \multicolumn{2}{|c|}{ Treatment } & \multicolumn{2}{|c|}{ Lake } & \multicolumn{2}{|r|}{ Season } & \multirow{2}{*}{$\begin{array}{c}\text { Lake } \times \\
\text { treatment } \\
P\end{array}$} & \multirow{2}{*}{$\begin{array}{c}\text { Lake } \times \\
\text { season } \\
P\end{array}$} & \multirow{2}{*}{$\begin{array}{c}\text { Treatment } \times \\
\text { season } \\
P\end{array}$} \\
\hline & & & $P$ & EMM & $P$ & EMM & $P$ & EMM & & & \\
\hline \multicolumn{12}{|l|}{ Pelagic food chain } \\
\hline Zooplankton & 18 & GLM & & & & & & & & & \\
\hline Planktivorous fish & 104 & RM LMM & & & $* * *$ & $\mathrm{G}>\mathrm{S}$ & & & & & $*$ \\
\hline \multicolumn{12}{|l|}{ Benthic food chain } \\
\hline Chironomidae & 69 & RM LMM & $* *$ & $\mathrm{r}<\mathrm{t}$ & & & $* *$ & $\mathrm{su}>\mathrm{sp}>\mathrm{au}$ & $* *$ & & $*$ \\
\hline + Trichoptera & 102 & RM LMM & $* *$ & $\mathrm{r}<\mathrm{t}$ & * & $\mathrm{G}>\mathrm{S}$ & * & $\mathrm{su}>\mathrm{sp}>\mathrm{au}$ & * & & \\
\hline Isopoda $\uparrow$ & 67 & RM LMM & $* * *$ & $\mathrm{r}<\mathrm{t}$ & * & $\mathrm{G}>\mathrm{S}$ & $*$ & $\mathrm{su}>\mathrm{sp}>\mathrm{au}$ & & & \\
\hline Isopoda $\ddagger$ & 51 & RM LMM & $* * *$ & $r<t$ & $* * *$ & $\mathrm{G}>\mathrm{S}$ & $* * *$ & $\mathrm{su}>\mathrm{sp}>\mathrm{au}$ & $* *$ & & \\
\hline \multicolumn{12}{|l|}{ Predatory } \\
\hline macroinvertebrates & 114 & RM LMM & & & $* * *$ & $\mathrm{G}>\mathrm{S}$ & ** & $\mathrm{su}>\mathrm{au}>\mathrm{sp}$ & & & $* *$ \\
\hline Omnivorous fish & 300 & RM LMM & $* * *$ & $r>t$ & $* * *$ & $\mathrm{G}>\mathrm{S}$ & $* *$ & $\mathrm{su}>\mathrm{au}>\mathrm{sp}$ & $* * *$ & * & $* * *$ \\
\hline Piscivorous fish & 32 & RM LMM & $*$ & $r>t$ & $* * *$ & $\mathrm{G}>\mathrm{S}$ & $* * *$ & $\mathrm{sp}>\mathrm{su}>\mathrm{au}$ & & & $* * *$ \\
\hline
\end{tabular}

Notes: For significant main effects, comparisons of estimated marginal means (EMM) are shown. Higher values of $\delta^{13} \mathrm{C}$ indicate higher reliance on terrestrial material. For treatment, $r$ stands for reference side, $t$ stands for treatment side (maize addition); for lake, $\mathrm{G}$ is Gollinsee, $\mathrm{S}$ is Schulzensee; and for season, sp is spring, su is summer, au is autumn. $N$ is the number of samples processed. No seasonal effects were calculated for zooplankton.

$\uparrow$ All individuals.

+ Individuals from leaf litter bags excluded.

$* P \leq 0.05 ; * * P \leq 0.01 ; * * * P \leq 0.001$.

2008) whose effect on the $\delta^{13} \mathrm{C}$ in the food web persists for less than one year.

The comparison of carbon influx and primary production indicated that autochthonous carbon fixation dominated organic carbon inputs, accounting for roughly $90 \%$ in the treatment sides of both lakes.
Accordingly, the tPOC input by maize only marginally changed the relative availability of autochthonous and allochthonous carbon in lakes at high nutrient loads (Carpenter et al. 2005). According to calculations using isotope mixing models, maize carbon contributed only minor proportions to the diet of macroinvertebrates (1-

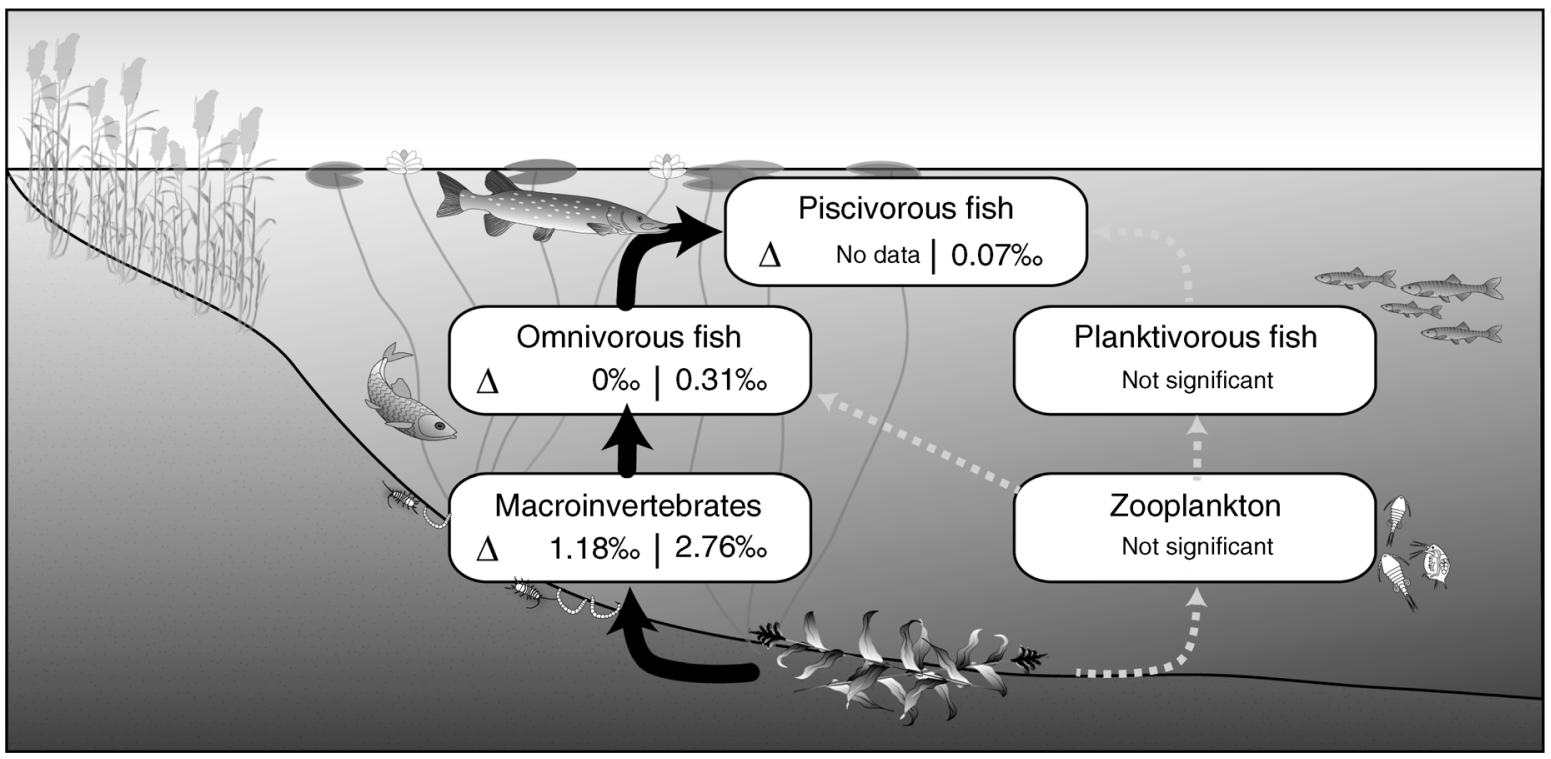

FIG. 4. Conceptual drawing of the pathway of experimentally added maize carbon in the food web of two shallow lakes. Depicted are isotopic enrichments (linear difference of $\delta^{13} \mathrm{C}$ values between treatment and references sides) of organisms collected in spring and summer, displayed as $\Delta$ (turbid) Gollinsee $\mid$ (clear) Schulzensee. No significant enrichment was found in the pelagic food web (i.e., zooplankton and planktivorous fish). In Gollinsee, no piscivorous fish were caught in the treatment side in spring and summer, therefore enrichment is shown only for Schulzensee. 
$11 \%$ of carbon) and omnivorous fish (1-3\%) in both lakes (see Scharnweber 2013 for details), thus reflecting the low share of maize carbon in the lake-wide carbon pools. Nevertheless, we could trace the uptake of maize carbon by elevations of $\delta^{13} \mathrm{C}$ in the benthic food web.

Our study extends previous approaches on the use of tPOC in lakes (Carpenter et al. 2005, Cole et al. 2006, Weidel et al. 2008, Solomon et al. 2011, Bartels et al. 2012) with respect to two major features. First, we supplied tPOC in a form (as leaves) and at a time (in late autumn) which best mimicked the naturally dominant litterfall to lakes. These features are important because the large physical size of leaves and their deposition immediately prior to the period with lowest annual temperatures (winter) may impede both immediate use and subsequent transformation of tPOC in the food web. Our experimental approach made it clear that tPOC from litterfall is processed relatively quickly in the first few months after supply because the allochthonous signal we detected already in spring could not have been caused by consumption and trophic transfer of old detritus from tPOC supplied in former years. Second, we supplied tPOC to natural lakes that contained pelagic and benthic primary consumers, but in addition had secondary, and even a few tertiary, consumers. Therefore, our results indicate that $\mathrm{tPOC}$ input during late autumn can be channeled up in lake food chains relatively rapidly, even to higher trophic levels. However, this channeling is primarily facilitated by the benthic pathway, whereas the trophic interactions across the pelagic pathway remained unaffected in terms of tPOC subsidies.

In contrast, Bartels et al. (2012) conducted mesocosm experiments with cornstarch as a tracer and found elevated values in invertebrate consumers, including pelagic zooplankton. Pelagic zooplankton can use tPOC primarily indirectly via feeding on bacteria or fungi which have used leachates from tPOC (Karlsson et al. 2003, Lennon and Pfaff 2005, Wurzbacher et al. 2010). Isotopic values of pelagic bacteria could not be measured in our experiment, but bacterial production increased for a few days immediately after maize addition in autumn 2010 in response to the higher carbon and nutrient availability from leachates (Attermeyer et al. 2013). However, this enhanced carbon availability did not persist long enough to shift the carbon values of zooplankton significantly relative to the reference sides, as evidenced by short tissue turnover rates in zooplankton (between $7.7 \mathrm{~d}$ in rotifers and 20.0 $\mathrm{d}$ in herbivorous crustaceans; Straile 1998). In addition to microbial transfer, zooplankton may receive a contribution from tPOC directly via feeding on seston that contains tPOC (Cole et al. 2006, Brett et al. 2009, 2012), a feeding mode which may in part explain how zooplankton may have directly used the fine-grained cornstarch in the enclosure experiments of Bartels et al. (2012). However, recent experiments have demonstrated that direct tPOC consumption by zooplankton is rather unlikely to support a large proportion of zooplankton production because of low assimilation of carbon, nitrogen, and fatty acids from tPOC relative to a diet of bacteria mixed with phytoplankton (Taipale et al. 2013). In contrast, there is considerable evidence that macroinvertebrate shredders directly use tPOC, in particular from leaves. It is not immediately clear why benthic macroinvertebrates are more efficient in using tPOC (compared to zooplankton), but it may be because they energetically profit from the accumulation of microbial biomass (especially fungi) on leaf surfaces (Cummins 1974, Gessner et al. 1999). Therefore, the benthic pathway predominantly channels tPOC into higher trophic levels (Anderson and Sedell 1979, Richardson 1992, Oertli 1993).

We had predicted that the response of the food webs to tPOC addition may differ between our study lakes because macroinvertebrate shredders that use tPOC from leaves are typically more abundant in nearshore habitats structured by macrophytes (Pardue and Webb 1985, Beckett et al. 1992, Hargeby et al. 2007) and hence omnivorous fish in these habitats may be more reliant upon macroinvertebrate prey (Okun et al. 2005). This assumption was confirmed. On average, maize shifted the $\delta^{13} \mathrm{C}$ of macroinvertebrates and fish by $1.73 \%$ in the lake with submerged macrophytes (Schulzensee) but only by $0.70 \%$ in the turbid Gollinsee. Furthermore, the enhanced $\delta^{13} \mathrm{C}$ was channeled up to piscivorous fish in Schulzensee, but faded out at trophic levels above macroinvertebrates in Gollinsee. Hence, we consider the stronger enhancement of $\delta^{13} \mathrm{C}$ in Schulzensee relative to Gollinsee as evidence for a more intense use of tPOC in the lake with a larger area covered by macrophytes. These findings agree with Brothers et al. (2013a), who found from mass balances that the overall carbon cycle in Schulzensee appeared to be more effective at processing carbon, resulting in higher surface emissions and lower carbon burial rates relative to Gollinsee. Currently, we can only speculate on potential processes causing higher use intensity of tPOC in structured habitats. Structural complexity in the littoral zone created by woody debris can prevent organic carbon transport by gravity and hydrodynamics to deeper waters and thus enhance the food availability for consumers in this habitat (Francis et al. 2007, Roth et al. 2007). Similarly, macrophytes promote structural complexity and may trap tPOC in the littoral zone (Vermaat et al. 2000). It can thus be assumed that tPOC from leaves is trapped in macrophyte-dominated littoral zones of clear-water lakes and hence consumers inhabiting these habitats are more reliant on tPOC than those living in nearshore zones of turbid lakes, as confirmed by our data. However, more research is needed on the habitat features that promote processing of tPOC in lakes.

In summary, our results provide the first direct experimental tracing of tPOC use across several trophic levels in lake food webs at the ecosystem scale and 
highlight the quantitative linkage of tPOC input from terrestrial surroundings to lentic food webs, similar to the strong aquatic-terrestrial coupling via tPOC repeatedly demonstrated for streams (Vannote et al. 1980, Nakano and Murakami 2001). The intensity of tPOC processing in lakes may depend on the structural complexity of the nearshore zones and hence may differ between shallow lakes of alternative stable states. For a more comprehensive mechanistic understanding of food web dynamics and carbon cycling in lakes, there is a need for an ecosystem approach that quantifies carbon from various autochthonous and allochthonous pathways and their contributions to primary and secondary production in various lake types.

\section{ACKNOWLEDGMENTS}

We thank A. Türck, C. Helms, J. Diekmann, J. Schreiber, S. Schuchort, S. Oksanen, and T. Wanke for their help in the field. We further acknowledge discussion and contributions by $\mathrm{R}$. Jones, S. Devlin, A. Vogt, K. Kuntze, M. Graupe, A. Busse, D. Thompson, S. Schmidt-Halewicz, B. Lischke, N. Meyer, N. Walz, U. Gaedke, H. P. Grossart, P. Casper, K. Premke, G. Nützmann, and M. Kaupenjohann. We thank K. Attermeyer for creating the conceptual graphic of carbon pathways. We especially appreciate the constructive comments on the manuscript by $\mathrm{M}$. Brett and two anonymous reviewers. Discussion of an early stage of the manuscript by the participants of the scientific writing workshop of the LeibnizInstitute of Freshwater Ecology and Inland Fisheries is particularly acknowledged. We thank K. Metzdorf (Technoplan Zelte und Planen $\mathrm{GmbH}$ ) for lake divisions. R. Mauersberger (Förderverein Feldberg-Uckermärkische Seen e.V.) and R. Tischbier (Stiftung Pro Artenvielfalt) kindly provided background information and access to the lakes. This study was financed by the TERRALAC-project (http://terralac. igb-berlin.de) of the Wissenschaftsgemeinschaft Leibniz (WGL). J. Syväranta and M. J. Vanni were supported by the IGB Fellowship program in Freshwater Science and K. Scharnweber was further supported by the German Academic Exchange Service (DAAD).

\section{Literature Cited}

Anderson, N. H., and J. R. Sedell. 1979. Detritus processing by macroinvertebrates in stream ecosystems. Annual Review of Entomology 24:351-377.

Attermeyer, K., K. Premke, T. Hornick, S. Hilt, and H.-P. Grossart. 2013. Ecosystem-level studies of terrestrial carbon reveal contrasting bacterial metabolism in different aquatic habitats. Ecology 94:2754-2766.

Babler, A. L., A. Pilati, and M. Vanni. 2011. Terrestrial support of detrivorous fish populations decreases with watershed size. Ecosphere 2:1-23.

Bartels, P., et al. 2012. Terrestrial subsidies to lake food webs: an experimental approach. Oecologia 186:807-818.

Beckett, D. C., T. P. Aartila, and A. C. Miller. 1992. Contrasts in density of benthic invertebrates between macrophyte beds and open littoral patches in Eau-Galle Lake, Wisconsin. American Midland Naturalist 127:77-90.

Brett, M., G. Arhonditsis, S. Chandra, and M. Kainz. 2012. Mass flux calculations show strong allochthonous support of freshwater zooplankton production is unlikely. PLoS ONE 7: e39508.

Brett, M., M. Kainz, S. Taipale, and H. Seshan. 2009. Phytoplankton, not allochthonous carbon, sustains herbivorous zooplankton production. Proceedings of the National Academy of Sciences USA 106:21197-21201.
Brothers, S. M., S. Hilt, K. Attermeyer, H. P. Grossart, S. Kosten, B. Lischke, T. Mehner, N. Meyer, K. Scharnweber, and J. Köhler. 2013a. A regime shift from macrophyte to phytoplankton dominance enhances carbon burial in a shallow, eutrophic lake. Ecosphere 4(11):art147.

Brothers, S. M., S. Hilt, S. Meyer, and J. Köhler. 2013b. Plant community structure determines primary productivity in shallow, eutrophic lakes. Freshwater Biology 58:2264-2276.

Carpenter, S. R., J. J. Cole, M. L. Pace, M. Van de Bogert, D. L. Bade, D. Bastviken, C. M. Gille, J. R. Hodgson, J. F. Kitchell, and E. S. Kritzberg. 2005. Ecosystem subsidies: terrestrial support of aquatic food webs from ${ }^{13} \mathrm{C}$ addition to contrasting lakes. Ecology 86:2737-2750.

Cole, J. J., S. R. Carpenter, M. L. Pace, M. C. Van de Bogert, J. L. Kitchell, and J. R. Hodgson. 2006. Differential support of lake food webs by three types of terrestrial organic carbon. Ecology Letters 9:558-568.

Cummins, K. W. 1974. Structure and function of stream ecosystems. BioScience 24:631-641.

Downing, J. A., et al. 2006. The global abundance and size distribution of lakes, ponds, and impoundments. Limnology and Oceanography 51:2388-2397.

Ehrlich, E. 2012. Einfluss von Fischsterben und allochthonem Material auf die Dynamik funktioneller Gruppen im Plankton von eutrophen Flachseen. Thesis. University of Potsdam, Potsdam, Germany.

Francis, T. B., D. E. Schindler, J. M. Fox, and E. SeminetReneau. 2007. Effects of urbanization on the dynamics of organic sediments in temperate lakes. Ecosystems 10:10571068.

Francis, T. B., D. E. Schindler, G. W. Holtgrieve, E. R. Larson, M. D. Scheuerell, B. X. Semmens, and E. J. Ward. 2011. Habitat structure determines resource use by zooplankton in temperate lakes. Ecology Letters 14:364-372.

Gessner, M. O. 2000. Breakdown and nutrient dynamics of submerged Phragmites shoots in the littoral zone of a temperate hardwater lake. Aquatic Botany 66:9-20.

Gessner, M. O., E. Chauvet, and M. Dobson. 1999. A perspective on leaf litter breakdown in streams. Oikos 85: $377-384$.

Gresens, S. E. 1995. Grazer diversity, competition and the response of the periphyton community. Oikos 73:336-346.

Hargeby, A., I. Blindow, and G. Andersson. 2007. Long-term patterns of shifts between clear and turbid states in Lake Krankesjon and Lake Takern. Ecosystems 10:28-35.

Heino, J. 2008. Patterns of functional biodiversity and function-environment relationships in lake littoral macroinvertebrates. Limnology and Oceanography 53:1446-1455.

Hesslein, R. H., K. A. Hallard, and P. Ramlal. 1993. Replacement of sulfur, carbon, and nitrogen in tissue of growing broad whitefish (Coregonus nasus) in response to a change in diet traced by $\delta 34 \mathrm{~S}, \delta 13 \mathrm{C}$, and $\delta 15 \mathrm{~N}$. Canadian Journal of Fisheries and Aquatic Sciences 50:2071-2076.

Jacob, M., K. Viedenz, A. Polle, and F. M. Thomas. 2010. Leaf litter decomposition in temperate deciduous forest stands with a decreasing fraction of beech (Fagus sylvatica). Oecologia 164:1083-1094.

Jansson, M., L. Persson, A. M. De Roos, R. I. Jones, and L. J. Tranvik. 2007. Terrestrial carbon and intraspecific sizevariation shape lake ecosystems. Trends in Ecology and Evolution 22:316-322.

Jones, R. I. 1992. The influence of humic substances on lacustrine planktonic food chains. Hydrobiologia 229:73-91.

Jones, R. I., J. Grey, D. Sleep, and L. Arvola. 1999. Stable isotope analysis of zooplankton carbon nutrition in humic lakes. Oikos 86:97-104.

Karlsson, J., A. Jonsson, M. Meili, and M. Jansson. 2003. Control of zooplankton dependence on allochthonous organic carbon in humic and clear-water lakes in northern Sweden. Limnology and Oceanography 48:269-276. 
Kritzberg, E. S., J. J. Cole, M. L. Pace, W. Graneli, and D. L. Bade. 2004. Autochthonous versus allochthonous carbon sources of bacteria: results from whole-lake ${ }^{13} \mathrm{C}$ addition experiments. Limnology and Oceanography 49:588-596.

Lennon, J. T., and L. E. Pfaff. 2005. Source and supply of terrestrial organic matter affects aquatic microbial metabolism. Aquatic Microbial Ecology 39:107-119.

Mehner, T., J. Ihlau, H. Dörner, and F. Hölker. 2005. Can feeding of fish on terrestrial insects subsidize the nutrient pool of lakes? Limnology and Oceanography 50:2022-2031.

Meyers, P. A., and E. Lallier-Verges. 1999. Lacustrine sedimentary organic matter records of Late Quaternary paleoclimates. Journal of Paleolimnology 21:345-372.

Nakano, S., and M. Murakami. 2001. Reciprocal subsidies: dynamic interdependence between terrestrial and aquatic food webs. Proceedings of the National Academy of Sciences USA 98:166-170.

Nowlin, W. H., M. J. Vanni, and L. H. Yang. 2008. Comparing resource pulses in aquatic and terrestrial ecosystems. Ecology 89:647-659.

Oertli, B. 1993. Leaf litter processing and energy flow through macroinvertebrates in a woodland pond (Switzerland). Oecologia 96:466-477.

Okun, N., W. C. Lewin, and T. Mehner. 2005. Top-down and bottom-up impacts of juvenile fish in a littoral reed stand. Freshwater Biology 50:798-812.

Pace, M. L., S. R. Carpenter, J. J. Cole, J. J. Coloso, J. F. Kitchell, J. R. Hodgson, J. J. Middelburg, N. D. Preston, C. T. Solomon, and B. C. Weidel. 2007. Does terrestrial organic carbon subsidize the planktonic food web in a clearwater lake? Limnology and Oceanography 52:2177-2189.

Pardue, W. J., and D. H. Webb. 1985. A comparison of aquatic macroinvertebrates occurring in association with Eurasian watermilfoil (Myriophyllum spicatum L.) with those found in the open littoral-zone. Journal of Freshwater Ecology 3:6979 .

Richardson, J. S. 1992. Food, microhabitat, or bothmacroinvertebrates use of leaf accumulations in a montane stream. Freshwater Biology 27:169-176.

Robinson, C. T., M. O. Gessner, and J. V. Ward. 1998. Leaf breakdown and associated macroinvertebrates in alpine glacial streams. Freshwater Biology 40:215-228.

Roth, B. M., I. C. Kaplan, G. G. Sass, P. T. Johnson, A. E. Marburg, A. C. Yannarell, T. D. Havlicek, T. V. Willis, M. G. Turner, and S. R. Carpenter. 2007. Linking terrestrial and aquatic ecosystems: the role of woody habitat in lake food webs. Ecological Modelling 203:439-452.
Scharnweber, K. 2013. The effect of structural complexity on ecological and evolutionary processes in shallow lake ecosystems. Dissertation, Freie Universität Berlin, Berlin, Germany.

Scheffer, M., S. H. Hosper, M. L. Meijer, B. Moss, and E. Jeppesen. 1993. Alternative equilibria in shallow lakes. Trends in Ecology and Evolution 8:275-279.

Schindler, D. E., and M. D. Scheuerell. 2002. Habitat coupling in lake ecosystems. Oikos 98:177-189.

Smith, B., and S. Epstein. 1971. Two categories of ${ }^{13} \mathrm{C} /{ }^{12} \mathrm{C}$ ratios for higher plants. Plant Physiology 47:380-384.

Solomon, C. T., S. R. Carpenter, M. K. Clayton, J. J. Cole, J. J. Coloso, M. L. Pace, M. J. Vander Zanden, and B. C. Weidel. 2011. Terrestrial, benthic, and pelagic resource use in lakes: results from a three-isotope Bayesian mixing model. Ecology 92:1115-1125.

Solomon, C. T., S. R. Carpenter, J. J. Cole, and M. L. Pace. 2008. Support of benthic invertebrates by detrital resources and current autochthonous primary production: results from a whole-lake ${ }^{13} \mathrm{C}$ addition. Freshwater Biology 53:42-54.

Straile, D. 1998. Biomass allocation and carbon flow in the pelagic food web of Lake Constance. Advances in Limnology 53:545-563.

Taipale, S., M. T. Brett, M. W. Hahn, D. Martin-Creuzburg, S. Yeung, M. Hiltunen, U. Strandberg, and P. Kankaala. 2013. Differing Daphnia magna assimilation efficiencies for terrestrial, bacterial, and algal carbon and fatty acids. Ecology 95: 563-576.

Tranvik, L. J., et al. 2009. Lakes and reservoirs as regulators of carbon cycling and climate. Limnology and Oceanography 54:2298-2314.

Vannote, R., G. Minshall, K. Cummins, J. Sedell, and C. Cushing. 1980. The river continuum concept. Canadian Journal of Fisheries and Aquatic Sciences 37:130-137.

Vermaat, J. E., L. Santamaria, and P. J. Roos. 2000. Water flow across and sediment trapping in submerged macrophyte beds of contrasting growth form. Archiv für Hydrobiologie 148: $549-562$.

Weidel, B., S. Carpenter, J. Cole, J. Hodgson, J. Kitchell, M. Pace, and C. Solomon. 2008. Carbon sources supporting fish growth in a north temperate lake. Aquatic Sciences 70:446458.

Wetzel, R. G. 1992. Gradient-dominated ecosystems: sources and regulatory functions of dissolved organic matter in fresh water ecosystems. Hydrobiologia 229:181-198.

Wurzbacher, C. M., F. Bärlocher, and H. P. Grossart. 2010. Fungi in lake ecosystems. Aquatic Microbial Ecology 59: $125-149$.

\section{Supplemental Material}

Appendix A

Organic carbon inputs, material, and methods (Ecological Archives E095-133-A1).

\section{Appendix B}

Zooplankton and macroinvertebrate species list, combined for Schulzensee and Gollinsee (Ecological Archives E095-133-A2).

\section{Appendix C}

Details of statistical analyses to compare carbon and nitrogen isotope signatures between lakes, treatments, and seasons (Ecological Archives E095-133-A3). 